\title{
Skala Prioritas Perencanaan Pembangunan Dalam Musrenbang Kecamatan
}

\author{
Mas Halimah ${ }^{1}$ \\ Ayi Karyana ${ }^{2}$
}

\begin{abstract}
Determination of development priorities proposed in the District Development Planning Meeting (Musrenbang) Pamulang district in 2012 involving actors from various components such as elements Muspika, District Government Elements, Elements Village Community Representative and Society, tend to be influenced and execute to achieve the vision, the mission of the Head area (Mayor) elected, in addition to carrying out the tradition of annual discussion forum that has become a liability in the district according to the instructions that have been prepared by the implementation of the Regional Government of South Tangerang City as an instance of the rules set down by the Ministry Of Home Affairs. The results of the analysis of the actors interaction involved in the process, activity and dynamics Musrenbangcam of the proposed agreement priority from each components showed different degrees in terms of sharpness proposed community priority. Proposed activities dominated bygoverment representative than village community representative and local businessman and infrastructure improvements rather than community empowerment programs.
\end{abstract}

Keywords: musrenbangcam (the district depelopment planning meeting), the scale of development priorities, musrenbang actors.

\begin{abstract}
Abstrak
Penetapan usulan skala prioritas pembangunan dalam Musyawarah Perencanaan Pembangunan Kecamatan (Musrenbang) Kecamatan Pamulang tahun 2012 yang melibatkan aktor-aktor dari berbagai komponen seperti dari unsur Muspika, Unsur Pemerintah Kecamatan, Unsur Perwakilan Kelurahan dan Unsur Masyarakat, cenderung dipengaruhi dan melaksanakan untuk meraih visi, misi dari Walikota terpilih, disamping untuk memenuhi tradisi forum musyawarah tahunan yang sudah menjadi kewajiban terstruktur di tingkat Kecamatan sesuai petunjuk pelaksanaan yang telah disusun oleh Pemerintah Daerah Walikota Tangerang Selatan sebagai turunan dari aturan yang disusun oleh Kementerian Dalam Negeri. Hasil analisis terhadap interaksi aktor-aktor yang terlibat dalam proses, aktivitas dan dinamika Musrenbangcam tentang kesepakatan usulan skala prioritas dari masingmasing komponen masyarakat menunjukkan derajat yang berbeda dalam hal ketajaman usulan prioritas kebutuhan masyarakat. Usulan lebih tajam dan didominasi oleh perwakilan aparat pemerintah ketimbang perwakilan dari unsur masyarakat dan pengusaha lokal, dan kegiatan perbaikan infrastruktur menjadi usulan paling utama ketimbang kegiatan pemberdayaan masyarakat.
\end{abstract}

Kata Kunci: musrenbangcam, skala prioritas pembangunan, aktor-aktor musrenbang.

Fakta menunjukkan dalam Musyawarah Perencanaan Pembangunan Kecamatan (Musrenbangcam) tahun 2012 yang dilaksanakan di wilayah Kota Tangerang Selatan, lebih dominan usulan ditetapkan berkenaan dengan bidang infrastruktur ketimbang kegiatan pemberdayaan masyarakat. Rata-rata rencana kegiatan infrastruktur mendapatkan alokasi dana besar, salah

\footnotetext{
${ }^{1}$ Dosen Kebijakan Publik Fisip Universitas Padjadjaran. Email : mas.halimah@unpad.ac.id

22Email : ayi@ecampus.ut.ac.id
} 
satunya dapat dilihat dalam pagu indikatif di Kecamatan Serpong tahun 2012 sebesar Rp 18,340 milliar. Meningkat dari tahun 2011 yang jumlahnya Rp13,505 milliar. Dalam Rekapitulasi Format 1, jumlah usulan anggaran pada Bidang infrastruktur sebesar Rp11.323.217.000, bidang kesehatan mencapai Rp1.283.350.000 dan pendidikan Rp4.534.050.000, serta bidang kebersihan, keamanan dan ketertiban $\mathrm{Rp}$ 746.600.000. Untuk bidang sarana dan prasarana Rp450.000.000 serta rehab total Kantor Kecamatan Serpong membutuhkan anggaran sebesar Rp5.000.000.000.

Dalam Format 2, jumlah anggaran bahan masukan Kecamatan Serpong sebagai Satuan Kerja Perangkat Daerah (SKPD) dalam rangka RPTK, bidang infrastruktur membutuhkan anggaran Rp2.575.350.000. Bidang Kesehatan Rp304.000.000, pendidikan Rp2.086.250.000, kebersihan keamanan dan ketertiban Rp 134.000.000, pada bidang sarana dan pra-sarana Rp176.000.000, ekonomi dan pertanian Rp420.000.000, keagamaan kemasyarakatan kepe-mudaan dan olahraga Rp8.857.900.000 serta bidang pembangunan sarana pemerintahan sebesar Rp6.625.000.000. Jika dikalkulasikan jumlah keseluruhan mencapai Rp21.178.500.000 (http://tangerangselatankota.go.id/read/news/ha sil-musrenbang, 16 April 2012).

Masalah penelitian dalam Musrenbangcam menurut pengamatan peneliti adalah: (1) dokumen perencanaan yang disusun para aktor belum menekankan pada perencanaan berbasis kebutuhan pokok masyarakat setempat; (2) dokumen perencanaan yang disusun cenderung masih berupa susunan usulan semata; (3) adanya ego sektoral/hegemoni kewenangan pusat di daerah dan hegemoni kewenangan dinas terkait/SKPD dalam bentuk kesulitan untuk melakukan koordinasi perencanaan; (4) persoalan perencanaan yang bersifat lintas sektor seringkali ditangani secara parsial; (5) data dan informasi yang berasal dari aktor masyarakat/Rukun Warga dan Kelurahan tidak lengkap dan komprehensif; (6) program dan kegiatan yang direncanakan masih belum disusun berdasarkan pada ketersediaan anggaran pada Pemerintah Kota; dan (7) sulit untuk memastikan adanya konsistensi antara program/kegiatan Satuan Kerja Perangkat Kota (SKPD/K) dan Kecamatan serta kebutuhan riil masyarakat dengan alokasi anggaran pada masing-masing satuan kerja secara pasti.

Sehubungan masalah tersebut, mendorong peneliti untuk mengetahui pelak-sanaan musrenbangcam dari aspek pemahaman musyawarah perencanaan pembangunan, penyusunan skala prioritas usulan perencanaan pembangunan, dan aktivitas aktor Musrenbangcam di Kecamatan Pamulang Kota Tangerang Selatan. Desain penelitian yang digunakan desain penelitian tipe deskriptif analisis pendekatan kualitatif (Arikunto, 2002). Sumber data dan informasi ditentukan secara purposive sesuai kepentingan dan keperluan analisis penelitian dari informan utusan Kelurahan, pejabat Bappeda Kota Tangerang Selatan, Dewan Perwakilan Rakyat Daerah (DPRD), peserta yang mewakili sektoral yang ada di Kecamatan Pamulang, Tokoh-tokoh masyarakat, Lembaga Swadaya Masyarakat (LSM), dan peserta lainnya. Langkah-langkah dalam analisis data yaitu editing, klasifikasi data, tabulasi dan interpretasi (Nazir, 2005).

\section{Musyawarah Perencanaan Pembangunan Kecamatan (Musrenbangcam) di Kecamatan Pamulang Kota Tangerang Selatan}

Untuk memahami nilai Musrenbang secara mendalam dalam kajian ini perlu dijelaskan secara etimologis pengertian dari musyawarah. Musyawarah berasal dari kata Syawara (Bahasa Arab) yang berarti berunding, urun rembug, atau mengatakan dan mengajukan sesuatu. Menurut istilah berarti perundingan antara dua orang atau lebih memutuskan suatu masalah secara bersama-sama. Istilah lainnya dalam tata negara Indonesia dan kehidupan modern tentang musyawarah dikenal dengan sebutan "syuro", "rembug desa", "kerapatan nagari" bahkan "demokrasi". Dengan kata lain, musyawarah merupakan suatu upaya untuk memecahkan persoalan dan mencari jalan keluar guna mengambil keputusan bersama dalam penyelesaian atau pemecahan masalah yang 
menyangkut urusan yang menjadi materi pembicaraan. (http://id.shvoong.com/socialsciences/education/2092968-pengertianmusyawarah/).

Kaitannya musyawarah dengan konsep pembangunan di Indonesia, Suadnya (2011) menguraikan pembangunan dalam hubungannya dengan perencanaan pembangunan yang spesifik di Indonesia adalah mulai diterapkannya people center orientation, yang bukan hanya menekankan pada pembangunan ekonomi (economic) tetapi pembangunan kesejahteraan sosial (sosial well being) dan kualitas dari lingkungan fisik (physical environment). Alasan utamanya, ketika manusia tidak menjadi pusat dari pembangunan, maka tidak ada pembangunan yang berarti dan berkesinambungan akan terlaksana. Begitu juga dengan aktivitas para aktor yang terlibat dalam Musrenbangcam harus sudah mulai memikirkan program dan kegiatan pemberdayaan masyarakat yang meningkatkan intensitas keterampilan dan keahlian.

Musrenbangcam merupakan musyawarah tahunan di tingkat Kecamatan untuk mendapatkan masukan, konfirmasi, klarifikasi, berbagai prioritas kegiatan berdasarkan hasil Musrenbang Desa/Kelurahan, program lintas Desa/Kelurahan, serta program internal Kecamatan sebagai dasar bagi penyusunan Rencana Program Kerja Kecamatan (RPTK). Kecamatan sebagai salah satu perangkat daerah kabupaten/kota memiliki kedudukan dan fungsi strategis. Dijelaskan oleh Wasistiono (2009) bahwa Kecamatan merupakan salah satu entitas pemerintahan yang memberikan pelayanan langsung maupun tidak langsung kepada masyarakat. Sebagai sub sistem pemerintahan di Negara Kesatuan Republik Indonesia (NKRI), Kecamatan memainkan peran fungsional dalam pelayanan dan administrasi pemerintahan, pembangunan serta kemasyarakatan. Untuk keperluan memberikan pelayanan sendiri, Kecamatan dalam setiap tahun anggaran mengusulkan daftar kegiatan prioritas yang akan dilaksanakan sendiri oleh Kecamatan dan menjadi Rencana Kerja (Renja) Kecamatan yang akan dibiayai melalui Anggaran Kecamatan yang bersumber dari Anggaran Pendapatan dan Belanja Daerah
(APBD) Kabupaten/Kota. Disamping itu, Kecamatan membuat daftar kegiatan Prioritas yang akan diusulkan ke Kabupaten/Kota yang disusun menurut Satuan Kerja Perangkat Daerah (SKPD) dan atau gabungan SKPD untuk dibiayai melalui anggaran SKPD yang bersumber dari APBD Kabupaten/Kota.

Sembiring dalam Jurnal Sosial dan Pembangunan MIMBAR (2012) dari hasil penelitiannya di Kecamatan Jatinangor Kabupaten Sumedang mengemukakan belum terwujud keseimbangan antara hak dan kewajiban kecamatan seiring dengan kendala yang dihadapi kecamatan yaitu kekurangan unsur 3P (Personalia, Pembiayaan dan Prasara \& Sarana) dalam merealisasikan tugas-tugasnya yang bersifat atribut dan tugas-tugas yang bersifat delegatif yang luas dan kompleks, kekurang jelasan kewenangan yang dilimpahkan oleh Bupati kepada Camat dan kurangnya upaya pemberdayaan pemerintah kecamatan sebagai pusat pelayanan kepada masyarakat. Kaitannya dengan situasi dan kondisi unsure 3P tersebut di wilayah Kecamatan Pamulang Kota Tangerang Selatan, memiliki kesamaan dengan Kecamatan Jatinangor, terutama dari sisi kompetensi sumber daya manusia (SDM).

Teknis pelaksanaan Musrenbang, setiap tahunnya di mulai dari Januari hingga Maret. Dalam waktu tiga bulan tersebut, Musrenbang tingkat kelurahan hingga tingkat kota harus selesai. Musrenbang di 54 kelurahan yang ada di Kota Tangerang Selatan dilakukan Januari. Musrenbang di 7 (tujuh) kecamatan yang ada, dilaksanakan Februari. Hasil dari Musrenbang tingkat kelurahan dan kecamatan tersebut disatupadukan dan disinergikan pada Maret di tingkat Forum SKPD atau Gabungan SKPD. Pada akhir Maret dilakukan Musrenbang tingkat kota yang hasilnya dibawa ke tingkat Provinsi dan Pusat.

Dalam praktek di lapangan seperti ditemukan dalam penelitian, penyelenggaraan pemerintahan, program, kegiatan pembangunan dan pelayanan publik oleh pemerintah atau perangkat pemerintah kabupaten/kota, ternyata masih didasarkan pada paradigma pendekatan legalitas. Pada saat merumuskan, menyusun dan 
menetapkan kebijakan selalu didasarkan pada pendekatan prosedur dan keluaran, dalam prosesnya menyandarkan atau berlindung pada peraturan perundang-undangan atau mendasarkan pada pendekatan legalitas dan pendekatan politis. Hal ini ditegaskan oleh informan dari Bappeda Kota Tangerang Selatan sebagai berikut (12 Desember 2012):

\begin{abstract}
Rencana Pembangunan Jangka Menengah Daerah 2011-2016 merupakan rujukan musrenbang, termasuk musrenbang kecamatan memuat arah kebijakan keuangan daerah, strategi pembangunan daerah, kebijakan umum, dan program satuan kerja perangkat daerah, lintas satuan kerja perangkat daerah, dan program kewilayahan disertai dengan rencana kerja dalam kerangka regulasi dan kerangka pendanaan yang bersifat indikatif.
\end{abstract}

Dokumen Rencana Pembangunan Jangka Menengah Daerah (RPJMD) 2011-2016 Kota Tangerang Selatan disusun berdasarkan pendekatan berikut: (1) pendekatan politik, pendekatan ini memandang bahwa pemilihan Kepala Daerah sebagai proses penyusunan rencana program, karena rakyat pemilih menentukan pilihannya berdasarkan programprogram pembangunan yang ditawarkan para calon Kepala Daerah. Dalam hal ini rencana pembangunan daerah adalah penjabaran agendaagenda pembangunan yang ditawarkan Kepala Daerah saat kampanye ke dalam RPJMD; (b) pendekatan Teknokratik, pendekatan ini dilaksanakan dengan menggunakan metode dan kerangka berpikir ilmiah oleh lembaga yang secara fungsional bertugas untuk hal tersebut; (3) pendekatan Partisipatif, pendekatan ini dilaksanakan dengan melibatkan pemang$\mathrm{ku}$ kepentingan (stakeholders) pembangunan. Pendekatan ini bertujuan untuk mendapatkan aspirasi dan menciptakan rasa memiliki; dan (4) pendekatan Atas-Bawah (top-down) dan BawahAtas (bottom-up), pendekatan ini dilaksanakan menurut jenjang pemerintahan. Hasil proses tersebut kemudian diselaraskan melalui musyawarah pembangunan.

Jika memperhatikan penjelasan di atas, forum Musrenbang yang dimulai dari Mus- renbang Kelurahan sampai Musrenbangcam merupakan forum yang cenderung melaksanakan dan untuk memenuhi aturan normatif, visi dan misi kepala daerah terpilih dan menyepakati usulan skala prioritas Pemerintah Kota Tangerang Selatan sesuai yang sudah ditentukan. Bappeda akhirnya yang menganalisis dan memilah semua usulan aspirasi dari warga yang dihasilkan musrenbang, baik Musrenbang Kelurahan maupun Musrenbangcam. Menyesuaikan dengan dana yang ada, tupoksi masingmasing SKPD, dan membuat program dan kegiatan sesuai urgensinya Pemerintah Kota. Selanjutnya, program dan kegiatan tersebut didistribusikan ke masing-masing dinas (SKPD). Misalnya terkait dengan pendirian Pendidikan Anak Usia Dini (PAUD), ini berkaitan dengan pendidikan di distribusikan ke Dinas Pendidikan. Jika warga Kelurahan meminta jalan di paving block atau betonisasi, maka aspirasi tersebut direkomendasikan untuk menjadi program dan kegiatan SKPD terkait (Dinas Bina Marga dan Sumberdaya Air).

Pemahaman terhadap Musrenbangcam akhirnya dinterpretasikan secara berbeda, tergantung dari kacamata yang melihatnya. Dalam kacamata warga musrenbangcam merupakan suatu agenda tahunan yang menjadi aktivitas rutin Kantor Kecamatan dan Kelurahan, dan hanya menjadi ajang silaturahmi biasa aktoraktor yang biasa diundang untuk berperan serta dalam menyusun usulan program dan kegiatan. Dapat terjadi program/kegiatan tidak sesuai dengan hasil musrenbang yang telah di laksanakan. Seringkali berbagai program dan kegiatan yang di hasilkan dalam musrenbang itu terelimininasi di kalangan atas/supra sistem. Dampak dari kejadian yang terus menerus terjadi seperti itu menjadikan warga mengambil alternatif hanya sekedar hadir dan diam, tidak menjadi masalah jika dana sudah turun dan menjadi kegiatan, wujud kegiatannya berbeda dengan yang dibutuhkan. Hal lain yang dikeluhkan oleh aktor yang berasal dari perwakilan warga adalah tidak adanya informasi dan konfirmasi dari hasil Musrenbangcam, program apa saja yang disepakati dan yang mana yang harus dibiaya secara swadaya masyarakat, 
prioritas kecamatan dan dibiayai dari APBD, dari mana dana anggarannya, bagaimana cara menindak lanjutinya, siapa yang memverifikasi kegiatan tersebut. Informasi yang diperlukan tersebut tidak sampai kepada masyarakat.

Peristiwa nyata dilapangan dialami oleh warga Kelurahan Pondok Cabe Ilir. Diantara mereka masih mempertanyakan mengenai fungsi Musrenbangcam, karena usulan dari mereka seringkali tidak diwujudkan, sedangkan proyek/kegiatan yang dibangun/dilaksanakan adalah kegiatan yang tidak diusulkan oleh warga. Dalam Musrenbangcam, warga Kelurahan Pondok Cabe Ilir mengusulkan 22 usulan kegiatan yang dibawa oleh 5 (lima) utusan mereka, masing-masing 1 (satu) perwakilan dari Badan Peberdayaan Masyarakat (BPM), 1 (satu) Ketua Forum RW, 1 (satu) orang perwakilan dari Tokoh Pemuda dan 2 (dua) orang perwakilan dari Tokoh Masyarakat.

Saya ingin memberikan tanggapan bahwa konsep bottom up sebenarnya sudah dilaksanakan dalam pelaksanaan Musrenbang Kecamatan di Kecamatan Pamulang ini. dan saya tahu usulan dibawa kedalam musrenbang kabupaten. hanya saja kemudian, usulan dari kelurahan dan masyarakat rukun warga, ketika sampai di kabupaten, saya dapat informasi habis dipangkas oleh anggota DPRD. dan berubah menjadi proyek pembangunan aspirasi anggota dewan. kendala yang lain katanya keterbatasan APBD, jadi tidak dapat menampung seluruh usulan warga (Warga, 06 November 2012).

Dari kacamata instansi, Musrenbangcam merupakan prasarana pembahasan usulan-usulan kegiatan yang diajukan, juga merupakan prasarana untuk melakukan koordinasi antara Kecamatan dengan SKPD yang terkait untuk sinkronisasi terhadap usulan-usulan kegiatan yang ada dalam pembangunan Prasarana Perkotaan. Prasarana oleh Pemerintah Kota Tangerang Selatan diartikan sebagai kelengkapan dasar fisik lingkungan yang memungkinkan lingkungan perumahan dan permukiman dapat berfungsi sebagaimana mestinya, antara lain seperti: jaringan jalan; jaringan saluran pembuangan air limbah; jaringan saluran pembuangan air hujan (drainase); dan tempat pembuangan sampah yang diakomodir dalam program dan usulan kegiatan SKPD terkait pada tahun anggaran selanjutnya. Sedangkan dari kacamata kalangan bisnis/niaga lokal sebagai ajang pendekatan resmi untuk kepentingan kelancaran bisnis/niaga di wilayah tempat mereka melakukan kegiatan bisnis/niaga. Ketika ditanyakan kepada aktor dari Kantor Kecamatan (18 Oktober 2012), terkait kasus yang dihadapi warga Kelurahan Pondok Cabe Ilir, jawabannya adalah sebagai berikut:

Masalahnya, masih banyak infrastruktur penting dan strategis yang belum kita penuhi, Ibu Walikota mengutamakan infrastruktur untuk jalan karena akan mendahulukan pelebaran jalan dulu agar kemacetan yang ada di kota Tanggerang Selatan ini teratasi, ya itu pertamanya, dan yang kedua ibu wali kota sudah merencanakan pembangunan gedung walikota Tangerang Selatan tapi masih ditunda karena untuk merapikan dulu jalan, agar kemacetan di Pamulang khususnya dan jalan di kota Tanggerang Selatan seluruhnya dapat teratasi dengan baik, karena infrastruktur itulah yang saat ini perlu didahulukan. Tujuannya untuk pembangunan inprastruktur segala macam apa kebutuhan masyarakat. Mana infrastruktur yang penting dulu yang diperlukan masyarakat, itu dahulu didahulukan, kebutuhan-kebutuhan masyarakat kita ajukan semuanya, dapat terjadi di tingkat atas kadang-kadang tidak diakomodasi dan akhirnya usulan warga tidak muncul.

Berkaitan dengan ragam program dan kegiatan yang menjadi agenda Musrenbangcam, aktor Kantor Kecamatan (18 Oktober, 2012) menjelaskan sebagai berikut.

Pelaksanaan program ada tiga jalur, nominal yang terbesar dari Musrenbang Kabupaten, Musrenbang Kecamatan dan Musrenbang Kelurahan. Program musrenbang ini merupakan modal awal di dalam mengusulkan program-program tahun 
mendatang. Selain itu ada juga top down planning, semacam bantuan dari pusat yang memang diusulkan serta diupayakan kepada Pemerintah Pusat. Program tersebut dalam bentuk program yang ada di semua kementerian, misal infra struktur, baik jalan terutama jalan nasional dan negara, pekerjaan umum, kesehatan masyarakat, koperasi dan lainnya. Itu memang program pusat dan daerah tinggal melaksanakan sesuai dengan petunjuk teknis yang ada. Ada juga program serap jaring aspirasi dari $D P R D$, itu juga merupakan acuan dalam menentukan prosentase program dari bawah.

Binsar (2010) menyatakan, kegagalan proses penyusunan perencanaan dapat terjadi karena aparat pelaksana yang tidak siap atau tidak kompeten, tidak memiliki kemampuan sehingga perencanaan mungkin baik, tetapi pelaksanaannya tidak seperti seharusnya. Salah satu penyebabnya adalah karena planning without facts artinya banyak perencana yang tidak paham akan masalah yang direncanakannya (planning in the dark). Untuk menghasilkan perencanaan program/kegiatan/urusan yang tepat sasaran, para pengusul kegiatan/urusan harus mengerti prosedur, tahapan perencanaan, langkah-langkah kegiatan, dan cara berkomunikasi dalam perencanaan pembangunan. Di sisi lain aktor pengusul harus paham substantif perencanaannya (ekonomi, fisik, sosial \& lingkungan). Pengusul kegiatan harus kreatif dalam memahami prosedur dan substantif perencanaan, dan harus terus berlatih dan selalu meng-update informasi dan data agar dapat memenuhi berbagai kebutuhan heterogen masyarakat. Aktor yang terlibat dalam musrenbang harus paham berkomunikasi, harus paham berpolitik, harus paham bernegosiasi, dan bertransaksi. Kemampuan lainnya, harus paham berkolaborasi \& bekerja sama. Hasil penelitian menunjukkan bahwa dalam menyusun usulan tidak hanya sekedar usulan, akan tetapi banyak faktor yang mengitarinya, sehingga setiap aktor yang berpartisipasi memiliki bekal pengetahuan yang cukup terkait dengan materi yang diusulkan.

Secara konsep, perencanaan memiliki banyak makna sesuai dengan pandangan masingmasing ahli dan berbagai kepentingan pemilik kebijakan. Menurut Rusmartini (2011) dalam tulisannya yang disponsori Provincial Governance Strengthening Programme (PGSP), Bappenas dan Kementerian Dalam Negeri menjelaskan, perencanaan adalah proses yang melibatkan berbagai pilihan misi dan tujuan serta tindakan yang diperlukan untuk mencapainya. Sebagai proses, perencanaan adalah netral secara ideologi dan dapat diterapkan pada tingkat perorangan, rumah tangga, perusahaan, pemerintah daerah maupun nasional. Dapat dikatakan, perencanaan adalah proses penetapan langkah-langkah program dan kegiatan untuk jangka waktu yang telah ditetapkan dengan memperhitungkan Sumber Daya Manusia (SDM) yang diperlukan dalam upaya mewujudkan pencapaian tujuan organisasi. Perencanaan merupakan salah satu fungsi manajemen untuk suatu proses penetapan komitmen organisasi dalam melakukan serangkaian tindakan tertentu secara sistematis sesuai dengan visi dan misi yang telah ditetapkan.

\section{Skala Prioritas Pembangunan dan Partisipasi Aktor Musrenbangcam di Kecamatan Pamu- lang Kota Tangerang Selatan}

Pertimbangan membuat keputusan menentukan pilihan usulan program dan kegiatan yang dipilih didasarkan kepada skala prioritas. Kurniasih (2005) menegaskan, skala prioritas sebuah proyek pembangunan dapat dinilai dari urgensitasnya, segi kemanfaatan, aspek pemeliharaan, cakupan masyarakat yang mendapatkan manfaat dari proyek pembangunan itu, dan kemampuan sumber daya yang ada. Skala prioritas pembangunan adalah proses memilih dari berbagai program dan kegiatan yang diusulkan aktor-aktor yang terlibat dalam perencanaan pembangunan dalam sebuah daftar usulan untuk mencapai efektivitas kerja yang tinggi sesuai dengan tujuan perencanaan pembangunan di daerah. Daftar Skala Prioritas (DSP) adalah instrumen yang dipergunakan untuk menilai, melakukan evaluasi dan memandu agar usulan program dan kegiatan/urusan yang 
berasal dari hasil Musyawarah Rukun Warga, Musrenbang Kelurahan dan Musrenbangcam menjadi fokus atau lebih menukik untuk mengatasi secara efektif berbagai isu dan permasalahan pembangunan Kecamatan.

Dalam pandangan teori seperti dikemukakan oleh Eko (2008), pada skala mikro perencanaan adalah langkah awal yang disiapkan untuk memulai kegiatan. Namun dalam konteks penyelenggaraan pemerintahan, pembangunan dan keuangan negara, perencanaan merupakan sebuah agenda yang sangat kompleks. Ia menjadi kompleks karena banyaknya kepentingan dalam masyarakat di tengah-tèngah kelangkaan (scarcity) sumberdaya. Para perencana, dan terutama pengambil kebijakan, akan menghadapi kesulitan dalam perencanaan mengingat jumlah orang yang terlibat terlalu banyak sementara jumlah sumberdaya (dana) sangat sedikit. Kelangkaan itulah yang membuat perencanaan sangat dibutuhkan, terutama untuk menentukan pilihan prioritas yang tepat dari sekian banyak kepentingan dan pilihan. Perencanaan di tingkat Kecamatan tidak luput dari berbagai kepentingan tersebut. Perencanaan pembangunan di tingkat Kecamatan agar berhasil harus mempelajari dan melihat dan didasarkan pada berbagai dokumen perencanaan terkait yang pernah ada pada tahun sebelumnya, baik komponen vertikal maupun horizontal yang berada dalam ruang lingkup Kecamatan. Komponen vertikal berasal dari supra sistem dan sektoral.

Akadun dalam Jurnal Sosial dan Pembangunan MIMBAR (2011) menemukan bahwa partisipasi masyarakat dalam proses perencanaan pembangunan masih terdapat banyak kelemahan terutama melalui jalur Musrenbang. Penyebabnya adalah usulan program/ proyek masyarakat melalui musrenbang tidak memiliki kepastian akan menjadi dokumen perencanaan pembangunan daerah setelah melewati proses legislasi antara Pemerintah Daerah dengan Dewan Perwakilan Rakyat Daerah (DPRD). Realitas menunjukkan telah terjadi kebohongan publik dan pelanggaran etika berdemokrasi dalam forum musrenbang sebagai wadah partisipasi masyarakat dalam penentuan kebijakan publik. Secara detail dijelaskannya bahwa kapasitas masyarakat dalam mengikuti proses perencanaan pembangunan masih lemah. Kelemahan ini di sebabkan model partisipasi masyarakat yang hanya menekankan model politis dan administratif, di samping perangkat hukum belum memberikan kerangka dan mekanisme bagaimana partisipasi masyarakat itu berlangsung. Oleh karena itu perlu mengembangkan model partisipasi masyarakat dalam proses perencanaan pembangunan dan atau mengimplementasikan model partisipasi alternatif seperti model pemberdayaan masyarakat serta setiap perangkat hukum harus memuat proses dan mekanisme partisipasi masyarakat dalam kegiatan yang diatur tersebut.

Partisipasi aktor dalam perencanaan pembangunan seharusnya menjadi jaminan dan sarana pemberdayaan warga Kecamatan. Dalam kenyataannya, posisi aktor warga dalam Musrenbangcam cenderung menduduki posisi lebih lemah dibandingkan dengan negara dan swasta/kalangan bisnis, untuk itu aktor warga sudah menjadi keharusan diberi kesempatan untuk mengemukakan usulannya dan mendapat kesempatan untuk berperan aktif dalam proses pengambilan keputusan. Manfaat dalam jangka panjang keterlibatan partisipasi aktif aktor warga adalah peningkatan keterampilan politik warga, karena sudah terbiasa bernegosiasi, melakukan kompromi, dan menyepakati berbagai hal kepentingan publik (termasuk kepentingan dan kebutuhan) warganya.

Memang selama ini sih kita kan mendapat
dari sana ya dari pemerintah kota, jadi
pemkot yang melaksanakan proyek, kita
tinggal mengikuti apa yang dilaksanakan,
kita hanya mengusulkan, melalui kelu-
rahan mengusulkan ke Kecamatan ke
walikota terus dari walikota turun dan
dilaksanakan (Rukun Warga, 06 Novem-
ber 2012).

Partisipasi dari elemen paling bawah di Kelurahan yaitu Rukun Warga (RW) patut diberdayakan, karena data masalah sebenarnya terdapat di tingkat RW. Aktor yang mewakili RW (06 November 2012) mengatakan. 
Musyawarah Rukun Warga sangat penting karena dari situlah muncul gagasan atau masukan di tingkat bawah yang perlu ditampung baik yang menyangkut kebutuhan warga, masalah riil yang ada di Rukun Warga yang bersangkutan, jadi sebenarnya usulan yang ada di kelurahan maupun kecamatan....ya datangnya dari $R W-R W$ tersebut.

Komentar salah satu aktor yang mewakili tokoh masyarakat (06 November 2012) berkomentar tentang partisipasi warga dalam musrenbang.

Terkadang, bahkan sering terjadi pada saat serap aspirasi tidak melibatkan berbagai elemen masyarakat, di kecamatan Pamulang ini kan sangat heterogen sekali elemen masyarakatnya, dari itu warga berharap, libatkan semua tokoh-tokoh yang ada, jangan hanya Lurah dan Ketua $R W$ saja yang datang, tapi elemen-elemen lainnya Kepala Sekolah, Ulama, Pengusaha dan lainnya yang berkontribusi terhadap gerak laju dan motor pembangunan di Kecamatan $\mathrm{Pa}$ mulang ini. Kalau memang tokoh-tokoh masyarakat, atau yang mewakili di undang dalam serap aspirasi maupun dalam musrenbang kecamatan maupun kelurahan maka apa yang diharapkan oleh masyarakat dan tokoh-tokoh masyarakat akan terwujud. Jadi tidak akan terjadi usulan tumpangan.

Pernyataan dari aktor Musrenbangcam dari Kelurahan Pondok Cabe Ilir (06 November) patut menjadi perhatian.

Melalui musrenbang diharapkan adanya partisipasi masyarakat untuk meMusyawarahkan sesuatu dan berakhir pada pengambilan kesepakatan atau pengambilan keputusan bersama. Seperti tahun-tahun sebelumnya, warga masih mengajukan proyek fisik seperti perbaikan saluran air, gorong-gorong, dan jalan lingkungan. Sedangkan untuk program non-fisik belum tersentuh oleh warga. Seharusnya, masyarakat yang mengikuti proses musrenbang memiliki akses dan kontrol terhadap pembuatan keputusan dan mendapat manfaat dari pelaksanaan keputusan tersebut. Diakui dari peserta musrenbang Kelurahan yang dihadiri oleh 32 peserta, masih didominasi oleh ketua rukun warga dan rukun tetangga, sedangkan elemen lainnya berhalangan hadir (Sekretaris Kel.Pd. Cabe Ilir - 06 November 2012).

Hasil analisis dokumen format 1 Daftar Usulan Kecamatan Pamulang tahun 2011, berbagai urusan/kegiatan yang diusulkan lebih terkait dengan infrastruktur, untuk kategori daftar usulan kegiatan Kecamatan terdiri dari 233 urusan/kegiatan; sedangkan daftar usulan kegiatan musrenbang RKPD terdapat 144 ren-cana tindak. Urusan/kegiatan yang berkaitan dengan urusan pemberdayaan masyarakat hampir tidak ada. Informan dari Kantor Kecamatan (25 Oktober 2012) menjelaskan.

Hal yang berkaitan dengan urusan pemberdayaan memang akan kita mulai dan dilaksanakan tahun 2013, tahun sebelumnya tidak direncanakan, maklum kota yang baru dimekarkan, jadi lebih ke pembenahan infrastruktur, pemerintah kota mulai tahun 2013 merencanakan untuk mengentaskan kemiskinan dengan pelatihan-pelatihan seperti security, sopir, pemberdayaan masyarakat, akan kita laksanakan. Sopir, komputer, kecantikan, semuanya sudah kita rencanakan. Identifikasi kelompok yang berkaitan dengan pemberdayaan masyarakat di Kecamatan Pamulang sudah kita identifikasi dan kita inventarisir, ini adalah kelompok pengrajin cenderamata. Contohnya di Kelurahan Benda itu dari anggrek, terus juga sudah ada kelompok batik dari Kelurahan Benda juga ya lumayan banyak juga sih.

Kusrini (2007) menjelaskan langkahlangkah yang dapat dilakukan dalam menyusun daftar skala prioritas adalah: (a) studi kelayakan/intelligence, pada langkah ini, sasaran ditentukan dan dilakukan pencarian prosedur, pengumpulan data, identifikasi masalah, identifikasi kepemilikan masalah, klasifikasi masalah, hingga akhirnya terbentuk sebuah pernyataan masalah; (b) perancangan/design, pada tahapan ini diformulasikan model yang akan digunakan dan kriterian- 
kriteria yang ditentukan, kemudian dicari alternatif model yang dapat dikembangkan untuk menyelesaikan masalah, selanjutnya memprediksi keluaran yang mungkin dan menentukan variabel-variabel model; (c) pemilihan/choice, menentukan berbagai alternatif model berserta variabel-variabelnya serta pemilihan modelnya, termasuk solusi dari model tersebut. Selanjutnya dilakukan analisis sensitivitas, yakni dengan mengganti beberapa variabel yang tidak relevan; dan (d) Membuat daftar skala prioritas yang benar-benar dibutuhkan masyarakat, terkait dengan perbaikan infrastruktur maupun dengan kegiatan pemberdayaan masyarakat.

Menurut Saaty (1995), untuk mengatasi berbagai persoalan yang dihadapi terkait dengan menyusun skala prioritas, penentuan skala 1 sampai 9 adalah skala terbaik untuk mengekspresikan pendapat. Ragam usulan yang dikemukakan oleh aktor peserta Musrenbangcam dapat diatasi dengan model skala perbandingan Saaty seperti digambarkan dalam tabel 2 nilai skala perbandingan berpasangan.

Tabel 2. Nilai Skala Perbandingan Berpasangan

beberapa hal yang perlu diperhatikan antara lain : (1) perencanaan program harus berdasarkan fakta dan kenyataan di masyarakat, (2) Program harus memperhitungkan kemampuan masyarakat dari segi teknik, ekonomi dan sosialnya, (3) Program harus memperhatikan unsur kepentingan kelompok dalam masyarakat, (4) Partisipasi masyarakat dalam pelaksanaan program (5) Pelibatan sejauh mungkin organisasi-organisasi yang ada (6) Program hendaknya memuat program jangka pendek dan jangka panjang, (7) Memberi kemudahan untuk evaluasi, (8) Program harus memperhitungkan kondisi, uang, waktu, alat dan tenaga (KUWAT) yang tersedia.

\section{Aktivitas aktor Musrenbangcam di Keca- matan Pamulang Kota Tangerang Selatan}

Hasil analisis tentang penggunaan paradigma pendekatan legalitas yang cenderung mengedepankan prosedur, hak, kewenangan dan kepentingan atas urusan yang melekat lebih mendominasi dan jika diamati lebih dalam, ternyata kurang memperhatikan prosesnya. Artinya, dalam proses merumuskan, menyusun dan menetapkan kebijakan, kurang optimal melibatkan aktivitas stakeholders atau aktor yang hadir dalam Musrenbangcam, tetapi cenderung dikendalikan melalui pendekatan politis oleh kekuatan yang memaksa dan dipaksakan untuk ditetapkan. Aktor yang hadir hanya sekedar mendengarkan program dan kegiatan, tidak melakukan proses aktivasi

Cahyono (2006), mengemukan pendapatnya bahwa proses perencanaan pembangunan berdasarkan partisipasi masyarakat harus memperhatikan adanya kepentingan rakyat yang bertujuan untuk meningkatkan kesejahteraan masyarakat, untuk itu dalam proses perencanaan pembangunan partisipasi ada perencanaan yang sebenarnya. Misalnya dengan usulan aktor dari pihak Pemerintah Kota yang yakin akan didanai, aktor dari kantor Kecamatan (18 Oktober 2012) memberikan pendapatnya:

Program-program yang berkaitan dengan fisik semuanya menjadi tanggungjawab 
satuan kerja perangkat daerah, satuansatuan kerja itulah yang menangani bidangbidang kegiatan sesuai tupoksinya. Jadi kantor kecamatan dalam musrenbangcam hanya sebagai fasilitator.

Dalam Musrenbangcam, aktivitas Bappeda adalah merangkum program dan kegiatan/urusan sesuai dengan agenda prioritas Pemerintah Kota. Terkait dengan tahapan Musrenbang, aktor dari Bappeda (12 Desember, 2012) menuturkan sebagai berikut:

Musrenbang terdiri dari beberapa tahapan. Dimulai dari tingkat kelurahan, selanjutnya tingkat kecamatan, naik ke tingkat kota, berlanjut ke tingkat provinsi hingga tingkat pusat. Dilakukan dari tingkat kelurahan sebagai bagian dari pelaksanaan pembangunan yang menganut asas bottom up planning. Hasil musrenbang itupun akan disepadankan dengan RTRW, RPJPD dan RPJMD yang sudah disusun sebelumnya atau asas top down planning, termasuk masukan dari anggota dewan. Dengan begitu tidak ada tumpang tindih dan tentunya tidak berbenturan dengan aturan dan keinginan warga soal pembangunan dapat direalisasikan.

Pihak Pemerintah Kota Tangsel yang diwakili oleh Bappeda sebagai narasumber Musrenbangcam yang sekaligus mewakili Walikota memberi arahan dan mengingatkan bahwa setiap program dan kegiatan di Kecamatan harus diselaraskan dengan kebijakan yang telah dikeluarkan yaitu harus sesuai dengan Rencana Tata Ruang Wilayah (RTRW), Rencana Pembangunan Jangka Pendek Daerah RPJPD), hingga Rencana Pembangunan Jangka Menengah Daerah (RPJMD).

Hasil wawancara dalam penelitian ini menunjukkan masih betapa kentalnya pengaruh legalitas dan pendekatan politis dalam proses penyusunan perencanaan pembangunan. Dikaji dari model perencanaan, hasil wawancara tersebut dapat dimaknai musrenbangcam yang diikuti oleh para aktor Kecamatan Pamulang yang diundang termasuk pada kategori model perencanaan oligarkhis (A, Abe, 2005). Peren- canaan oligarkhis adalah perencanaan yang dirumuskan oleh segelintir orang terutama pihak pemerintah kota, dalam hal ini Bappeda Kota Tangerang Selatan dan DPRD. Secara aturan, kedua institusi ini memiliki legalitas/ kewenangan formal dan absah untuk membuat keputusan, termasuk keputusan dalam memilih prioritas kegiatan yang akan mendapat biaya dari Anggaran Pembangunan dan Belanja Daerah (APBD). Namun, secara teori, perencanaan model oligarkhis ini umumnya tidak elitis, tidak demokratis dan sentralistik.

Aktor lainnya dalam Musrenbangcam berasal dari anggota DPRD dari wilayah pemilihan Kecamatan/kelurahan yang bersangkutan. Musyawarah ini bagi anggota DPRD, dijadikan forum untuk menjaring aspirasi masyarakat (jaring asmara). Informan dari anggota DPRD (12 Desember 2012) mengemukakan pendapatnya.

Musrenbang kecamatan merupakan wahana perencanaan pembangunan partisipatif seluruh masyarakat. Dengan demikian diharapkan menelurkan program perencanaan yang benar-benar super prioritas, realistis dan berkualitas berdasarkan kebutuhan masyarakat. Oleh karena itu kegiatan musrenbang vang hendaknya dimanfaatkan dengan sebaik-baiknya agar berdaya guna dan berhasil guna dengan sasaran akhir terwujudnya peningkatan kesejahteraan masyarakat.

Pendapatnya tentang kualitas hasil Musrenbangcam, aktor dari DPRD (12 Desember 2012) mengatakan.

Kualitas hasil Musrenbang Kecamatan seringkali rendah karena kurangnya fasilitator musrenbang yang berkualitas. Fasilitasi proses perencanaan tingkat kelurahan yang diamanahkan untuk dilaksanakan oleh pemerintah kota, dapat melalui jalur Kecamatan seringkali tidak berjalan. Proses fasilitasi hanya diberikan dalam bentuk surat edaran agar kelurahan melakukan musrenbang, dan jarang dalam bentuk bimbingan fasilitasi di lapangan. Itu kenyataan yang tidak terbantahkan sampai saat ini. Ke depan perlu direformasi. 
Aktor peserta dari Kecamatan dan kelurahan, ketika dikonfirmasi tentang pendapat dari aktor anggota DPRD (12 November 2012), memberikan tanggapan berikut.

Intervensi hak budget DPRD terlalu kuat dimana anggota DPRD sering mengusulkan kegiatan-kegiatan yang menyimpang jauh dari usulan masyarakat yang dihasilkan dalam Musrenbang. Jadwal reses DPRD dengan proses Musrenbang yang tidak match misalnya Musrenbang sudah dilakukan, baru $D P R D$ reses mengakibatkan banyak usulan DPRD yang kemudian muncul dan merubah hasil Musrenbang.

Dengan pencermatan (scanning) terhadap hasil analisis aktivitas interaksi aktor-aktor yang terlibat dalam Musrenbangcam di Kecamatan Pamulang dapat diidentifikasi kekuatan, kelemahan, peluang dan ancaman dalam kegiatan Musrenbangcam seperti tersaji dalam tabel 1 . kepentingan kelembagaan dari aktor-aktor yang mewakili pemerintah kota (unsur Bappeda) dan Dinas-dinas Kota. Daftar usulan hasil Musrenbang Kelurahan dalam Musrenbangcam dipatahkan oleh kepentingan Pemerintah Kota dengan alasan keterbatasan anggaran dan prioritas pem-bangunan untuk mewujudkan visi, misi Pemerintah Kota/kepentingan politis. Penye-lenggaraan Musrenbang Kecamatan terkesan hanya sekedar formalitas untuk memenuhi mekanisme perencanaan pembangunan. Aktor-aktor dari elemen masyarakat tidak berdaya untuk memperkuat usulannya yang sebenarnya usulan tersebut merupakan kebutuhan riil masyarakat setempat.

Menurut Adisasmita (2011), seharusnya, Pemerintah berfungsi menciptakan lingkungan politik dan hukum yang kondusif. Pihak swasta menyediakan lapangan pekerjaan dan menciptakan pendapatan, sedangkan masyarakat berperan positif dalam interaksi sosial, ekonomi, dan politik, termasuk mengajak kelompok-

\section{Tabel 1. Pencermatan SWOT Musrenbangcam di Kecamatan Pamulang}

\begin{tabular}{|c|c|}
\hline KEKUATAN (Strengths): & KELEMAHAN (Weaknesses): \\
\hline $\begin{array}{l}\text { 1. Jumlah aktor yang bermusyawarah memadai ( } 50 \\
\text { peserta) } \\
\text { 2. Sebagai SKPD tersendiri yang memiliki sebagian } \\
\text { kewenangan Walikota } \\
\text { 3. Uraian tugas musyawarah jelas } \\
\text { 4. Adanya pedoman dan juknis musrenbangcam } \\
\text { 5. Kesadaran seluruh aktor untuk berpartisipasi } \\
\text { 6. Memiliki } 8 \text { (delapan) Kelurahan, } 781 \mathrm{RT}, 152 \mathrm{RW} \\
\text { 7. Adanya penguatan informasi dari Media Massa }\end{array}$ & $\begin{array}{l}\text { 1. Kualitas aktor peserta musrenbangcam kurang } \\
\text { 2. Dokumen Rencana Pembangunan Jangka } \\
\text { menengah (RPJM) Kelurahan umumnya tidak } \\
\text { dibuat/tidak ada } \\
\text { 3. Daftar prioritas dari RW umumnya belum ada. } \\
\text { 4. Belum semua kelompok perwakilan di } \\
\text { kecamatan hadir dalam musrenbangcam } \\
\text { 5. Musrenbang di RW dan kelompok masyarakat } \\
\text { 6elum dilaksanakan dan masyarakat kecamatan } \\
\text { 7idak ada evaluasi dari } \\
\text { 7. Pemberian informasi dari kecamatan dan kota } \\
\text { 8. Pelum dilaksanakan } \\
\text { pengumuman terbuka dan pendaftaran terbuka } \\
\text { dilaksanakan }\end{array}$ \\
\hline PELUANG (Opportunities): & ANCAMAN (Threats): \\
\hline
\end{tabular}

Aktivitas aktor Musrenbangcam di Kecamatan Pamulang terkesan hanya melaksanakan amanat perundang-undangan, bukan mengeksplorasi kebutuhan yang sebenarnya. Dalam Musrenbangcam terjadi pemaksaan kelompok dalam masyarakat untuk berpartisipasi dalam aktivitas produktif dan pemberdayaan masyarakat. Warga masyarakat perlu bersikap mengoreksi jalannya program dan kegiatan pemerintahan daerah dan pembangunan yang 
dilaksanakan di Kecamatan sebagai bentuk kontrol dari warga yang peduli terhadap jalannya pembangunan daerah. Sebaliknya pemerintah daerah menerima masukan dari masyarakat sebagai bagian dari keterbukaan dan tanggung gugatnya.

\section{Kesimpulan dan Saran}

Berdasarkan hasil kajian teori dan pembahasan maka diambil kesimpulan sebagai berikut:

1. Hasil kajian menunjukkan derajat yang berbeda dalam hal pemahaman musrenbangcam, hal ini dipengaruhi oleh faktor kepentingan (vested interest), kekurangmampuan para aktor tentang pengetahuan kondisi rukun warga dan kelurahan yang sebenarnya dan kegiatan/ kebutuhan mendasar yang dibutuhkan masyaraka, sehingga usulan dalam musyawarah didominasi oleh kegiatan perbaikan infrastruktur ketimbang program pemberdayaan masyarakat.

2. Skala prioritas perencanaan pembangunan dalam Musrenbang di Kecamatan Pamulang Kota Tangerang Selatan tahun 2012 yang melibatkan aktor-aktor dari berbagai komponen seperti dari unsur Muspika, Unsur Pemerintah Kecamatan, Unsur Perwakilan Kelurahan dan Unsur Masyarakat, cenderung dipengaruhi dan melaksanakan untuk meraih visi, misi dari Walikota terpilih, di samping untuk melaksanakan tradisi forum musyawarah tahunan yang sudah menjadi kewajiban di tingkat Kecamatan sesuai petunjuk pelaksanaannya yang telah disusun oleh Pemerintah Daerah Walikota Tangerang Selatan sebagai turunan dari aturan yang disusun oleh Kementerian Dalam Negeri.

3. Aktivitas aktor musrenbangcam dipengaruhi oleh visi, misi dari Pemerintah Kota dan melaksanakan tradisi yang sudah terbiasa terjadi setiap tahun.

Berdasarkan pada kesimpulan tersebut, dikembangkan saran sebagai berikut.

1. Berdasarkan dari hasil kajian, direko- mendasikan Kecamatan/Kota membentuk dan merancang model perencanaan pembangunan yang berbasis pada kesejahteraan masyarakat serta menerapkannya dalam setiap pelaksanaan Musrenbang di mulai dengan Musrenbang Rukun Warga berbasis data, dilanjutkan dengan Musrenbang Kelurahan dan Musrenbang Kecamatan. Delegasi dari RW dan unsur-unsur kelurahan membahas minimal lima atau enam kelompok usulan skala prioritas program atau kegiatan inti, yaitu ekonomi, pendidikan, kesehatan, sosial budaya, sarana prasarana, serta ketenteraman dan ketertiban. Dalam diskusi, usulan skala prioritas program dan kegiatan setiap kelompok dibahas dan dianalisis menggunakan enam kriteria, yaitu kemanfaatan, kemendesakan, ketersediaan potensi, keberlanjutan, ketersediaan dukungan masyarakat, dan tidak berdampak negatif terhadap lingkungan. Sebelum proses ini berlangsung, ada pelatihan fasilitator yang terlatih dan terdidik untuk mendampingi peserta Musrenbangcam dan memberi penjelasan secara detail tentang pengelompokan usulan program dan kegiatan, daftar harapan, daftar permasalahan, kriteria, pemberian bobot dan perankingan yang menghasilkan prioritas. Dengan hasil ini, setiap warga dapat mengetahui usulan dari Rukun Warga atau lingkungan yang menjadi prioritas usulan program dan kegiatan. Hal mendasar ini sebagai tanggung jawab untuk mengawali hasil Musrenbang di Kelurahan/Kecamatan agar tidak hilang atau tercecer pada proses Musrenbang di atasnya. Jika ada usulan masyarakat yang hilang atau tidak menjadi prioritas, maka harus ada alasan yang dapat dikomunikasikan kepada masyarakat dan diterima warga yang mengusulkannya. Evaluasi dilakukan oleh tim independen dari perguruan tinggi, termasuk sesudah program dan urusan/ kegiatan selesai dilaksanakan.

2. Mengembangkan Model Musrenbangcam yang secara efektif memberi ruang dan kesempatan lebih besar dan luas kepada actor warga untuk terlibat aktif dalam proses 
musrenbang dari tingkat Rukun Warga, Kelurahan, Kecamatan hingga Pemerintah Kota. Aktor warga berdasarkan skala prioritas riil memutuskan skala prioritas program dan kegiatan pembangunan wilayah, dengan tetap memperhatikan kriteria skala prioritas Pemerintah Kota. Pihak atau institusi dari luar masyarakat hanya sebagai fasilitator dan narasumber. Dengan cara itu, Musrenbangcam dimaknai sebagi forum actor warga untuk membahas, mendialogkan, berkonsultasi, dan menyepakati program dan kegiatan pembangunan wilayahnya sesuai kebutuhan dan prioritas warga dan dianggarkan dalam Anggaran Pendapatan dan Belanja (APBD) Kota Tangerang Selatan.

\section{DAFTAR PUSTAKA}

\section{A. Buku \& Jurnal/Hasil Penelitian}

Abe, Alexander. (2005). Perencanaan Daerah Partisipatif. Yogyakarta: Pokja Pembaharuan.

Adisasmita, Rahardjo.(2011). Manajemen Pemerintah Daerah. Yogyakarta: Graha Ilmu.

Akadun, A. (2012). Revitalisasi Forum Musrenbang Sebagai Wahana Partisipasi Masyarakat dalam Perencanaan Pembangunan Daerah. MIMBAR,27(2), 183192.

Arikunto, S. (2002). Prosedur Penelitian (suatu pendekatan praktek). Jakarta: Rineka Cipta.

Binsar PHN.(2010). Tantangan Peningkatan Kualitas Kompetensi Perencana Pembangunan. Simpul Perencana. Volume 15|Tahun 7|Desember 2010. Jakarta: Pusbindiklatren Bappenas.

Cahyono. B.Y. (2006). Metode Pendekatan
Sosial Dalam Pembangunan Partisipatif.

lppm.petra.ac.id/ppm/COP/download. Di akses, 2 November 2007.

Eko, Sutoro.(2008). Pro poor budgeting: Politik baru reformasi anggaran daerah Untuk pengurangan kemiskinan. Workingpaper/eko/iv/june/2008. Yogyakarta: IRE.

Kurniasih, Dewi. (2005). Model Skala Prioritas Pembngunan Kota Bandung Berbasis Good Governance. Makara Sosial Humaniora, Vol. 9, No. 2, Desember 2005: $72-83$.

Kusrini. (2007). Konsep dan Aplikasi Sistem Pendukung Keputusan. Yogyakarta: Penerbit Andi.

Nazir, Moh. (2005). Metode Penelitian. Jakarta: Ghalia Indonesia, Gunung Agung.

Rusmartini, Arum. (2011). Pokok-pokok Pikiran dalam Rangka Penyempurnaan Penyelenggaraan Musyawarah Perencanaan Pembangunan (Musrenbang). Policy Issues Paper. Jakarta: Provincial Governance Strengthening Programme.

Wasistiono, Sadu, dkk. (2009). Perkembangan Organises Kecamatan dari Masa ke Masa. Bandung: Fokusmedia.

Saaty, T. L. (1995). Decision Making for Leaders: The Analytical Hierarchy Process for Decisions in a Complex World, Rev. ed. Pittsburgh: RWS Publishers.

Sembiring, Masana.(2012). Pelaksanaan Tugas Kecamatan Guna Memberdayakan Pemerintah sebagai Pusat Pelayanan Masyarakat. Dalam Jurnal Mimbar, Vol XXVIII, No. 1 (Juni, 2012): 1- 8.

Suadnya, I Wayan (2011). Perencanaan 
Partisipatif Dalam Pembangunan Daerah di Kabupaten Lombok Barat: Antara Konsep dan Realita. Jurnal Agroteksos Vol. 21 No.1, April 2011.

\section{B. Peraturan Perundang-Undangan}

Peraturan Daerah Nomor 6 Tahun 2010 Tentang Organisasi Perangkat Daerah Kota Tangerang Selatan.

Peraturan Daerah Kota Tangerang Selatan Nomor 11 Tahun 2011 tentang Rencana Pembangunan Jangka Menengah Daerah Kota Tangerang Selatan 20112016.

Peraturan Daerah Nomor 15 Tahun 2011 tentang Rencana Tata Ruang Wilayah Kota Tangerang Selatan 2011 - 2032.

http://id.shvoong.com/sosial-

sciences/education/2092968-pengertian musyawarah/\#ixzz1oIWJKOMt, 07 Maret 2012.

http://tangerangselatankota.go.id/read/news/hasi 1-musrenbang, 16 April 2012. 